\title{
Controlling the Colonization of Clostridium perfringens in Broiler Chickens by an Electron-Beam-Killed Vaccine
}

\author{
Palmy R. Jesudhasan ${ }^{1}$ (), Sohini S. Bhatia ${ }^{2}$, Kirthiram K. Sivakumar ${ }^{2}$, Chandni Praveen $^{2}$, Kenneth J. Genovese ${ }^{3}$, \\ Haiqi L. He ${ }^{3}$, Robert Droleskey ${ }^{3}$, Jack L. McReynolds ${ }^{4}$, James A. Byrd ${ }^{3}$, Christina L. Swaggerty ${ }^{3}{ }^{(0}$, \\ Michael H. Kogut ${ }^{3}{ }^{(0}$, David J. Nisbet ${ }^{3}$ and Suresh D. Pillai ${ }^{2, *}$ \\ 1 Poultry Production and Product Safety, USDA-ARS, 1260 W Maple St., O-306 POSC Building, University of \\ Arkansas, Fayetteville, AR 72701, USA; Palmy.Jesudhasan@usda.gov \\ 2 National Center for Electron Beam Research, An IAEA Collaborating Centre for Electron Beam Technology, \\ Texas A\&M University, College Station, TX 77843, USA; sohinibhatia@tamu.edu (S.S.B.); \\ kirthiramsivakumar@gmail.com (K.K.S.); Chandni.vs@gmail.com (C.P.) \\ 3 Food and Feed Safety Research Unit, USDA-ARS, $2881 \mathrm{~F}$ and B Rd, College Station, TX 77845, USA; \\ kenneth.genovese@usda.gov (K.J.G.); haiqi.he@usda.gov (H.L.H.); bob.droleskey@usda.gov (R.D.); \\ Allen.Byrd2@usda.gov (J.A.B.); christi.swaggerty@usda.gov (C.L.S.); mike.kogut@usda.gov (M.H.K.); \\ david.nisbet@usda.gov (D.J.N.) \\ 4 Arm \& Hammer Animal and Food Production, Church \& Dwight Co. Inc., 6935 Vista Drive, \\ West Des Moines, IA 50266, USA; Jackson.McReynolds@churchdwight.com \\ * Correspondence: s-pillai@tamu.edu; Tel.: +1-979-458-3229
}

\section{check for} updates

Citation: Jesudhasan, P.R.; Bhatia, S.S.; Sivakumar, K.K.; Praveen, C.; Genovese, K.J.; He, H.L.; Droleskey, R.; McReynolds, J.L.; Byrd, J.A.; Swaggerty, C.L.; et al. Controlling the Colonization of Clostridium perfringens in Broiler Chickens by an Electron-Beam-Killed Vaccine. Animals 2021, 11, 671. https:// doi.org/10.3390/ani11030671

Academic Editor: Amit Vikram

Received: 20 January 2021

Accepted: 22 February 2021

Published: 3 March 2021

Publisher's Note: MDPI stays neutral with regard to jurisdictional claims in published maps and institutional affiliations.

Copyright: (c) 2021 by the authors. Licensee MDPI, Basel, Switzerland. This article is an open access article distributed under the terms and conditions of the Creative Commons Attribution (CC BY) license (https:/ / creativecommons.org/licenses/by/ $4.0 /)$.
Simple Summary: Clostridium perfringens $(\mathrm{Cp})$ is a bacterium that causes necrotic enteritis in chickens and is responsible for an economic loss of about 6 billion U.S. dollars in the poultry industry worldwide. Consumption of $\mathrm{Cp}$ contaminated chicken meat causes foodborne illnesses in humans. Although $\mathrm{Cp}$ can be controlled in chickens by administering antibiotics through feed and water, the ban on the antibiotics owing to concerns on antibiotic resistance has created the need to identify alternative control approaches. As vaccination could be used as an alternative, we used electron beam irradiation (eBeam) to kill the bacterium and use the killed cells as vaccine to control the colonization of $\mathrm{Cp}$ in broiler chickens. In this study, we exposed three different strains of $\mathrm{Cp}$ to eBeam irradiation and used them as a vaccine to day-18 embryos. After the embryos hatched, the birds in each treatment were segregated into two groups for live $\mathrm{Cp}$ challenge at two time points. The results indicate that the vaccine effectively controlled the colonization of all three strains of $C p$ when challenged with live $\mathrm{Cp}$, indicating that the vaccinated birds had acquired immunity. The current approach can reduce $\mathrm{Cp}$ colonization in chickens, thereby reducing economic loss.

Abstract: Clostridium perfringens ( $\mathrm{Cp}$ ) is a Gram-positive anaerobe that is one of the causative agents of necrotic enteritis (NE) in chickens, which leads to high mortality. Owing to the ban of administering antibiotics in feed to chickens, there has been an increase in the number of NE outbreaks all over the world, and the estimated loss is approximately 6 billion U.S. dollars. The best alternative method to control NE without antibiotics could be vaccination. In this study, we exposed three different strains of $\mathrm{Cp}$ to electron beam (eBeam) irradiation to inactivate them and then used them as a killed vaccine to control the colonization of $\mathrm{Cp}$ in broiler chickens. The vaccine was delivered to 18-day old embryos in ovo and the chickens were challenged with the respective vaccine strain at two different time points (early and late) to test the protective efficacy of the vaccine. The results indicate that an effective eBeam dose of $10 \mathrm{kGy}$ inactivated all three strains of $\mathrm{Cp}$, did not affect the cell membrane or epitopes, induced significant levels of IgY in the vaccinated birds, and further reduced the colonization of Cp strains significantly $(p<0.0001)$ in late challenge (JGS4064: 4 out of 10; JGS1473: 0 out of 10; JGS4104: 3 out of 10). Further studies are necessary to enhance the efficacy of the vaccine and to understand the mechanism of vaccine protection.

Keywords: electron beam irradiation; eBeam; eBeam-killed vaccine; Clostridium perfringens; broiler chickens; in ovo vaccination; embryo vaccination; challenge 


\section{Introduction}

Clostridium perfringens ( $\mathrm{Cp}$ ) is a Gram-positive, rod-shaped, spore-forming, anaerobic bacterium that causes several human and animal diseases and is considered the most important clostridial pathogen of poultry [1]. Cp is also a foodborne pathogen causing 19 outbreaks and 478 illnesses in the United States annually (CDC 2019). This bacterium, along with other predisposing factors, causes necrotic enteritis (NE) in broiler chickens aged 2 to 6 weeks old [2,3] and is associated with mucosal damage in the intestine [4]. NE causes up to $30 \%$ mortality in broiler chickens, costing the worldwide poultry industry approximately $\$ 6$ billion U.S. dollars annually [5], and causes an estimated $\$ 342$ million loss in the United States due to foodborne illnesses [6]. For more than forty years, poultry feed and water have been supplemented with antibiotics to improve poultry growth performance and feed efficiency, with the added benefit of protecting poultry from the harmful effects of enteric microorganisms [7]. However, concerns about increased spread of antibiotic resistance markers [8,9] have led to the discontinued use of antibiotic growth promoters in much of the global poultry industry. With the decreased use of antimicrobial drugs, however, there has been an increase of NE in poultry from approximately $4 \%$ to $12 \%$ [10-12].

$\mathrm{Cp}$ produces several potent protein toxins that are important to its virulence and, based on these toxins, $C p$ strains are classified into seven types, designated A-G $[13,14]$. Types $A$ and $C$ are known to cause NE in chickens [15]. The $\alpha$-toxin, a major secretory protein of $\mathrm{Cp}$ produced by all $\mathrm{Cp}$ strains, was once considered the essential virulence factor in the pathogenesis of NE [4]; however, numerous studies have demonstrated that $\alpha$-toxin knockout mutants are still capable of inducing disease $[3,12,16,17]$. Other studies have reported that NetB toxin, and not $\alpha$-toxin, is the essential virulence factor in NE infection $[15,16]$. Cp strains producing both NetB and TpeL are considered more virulent in producing NE $[18,19]$. There is conflicting evidence of these toxins' prevalence and importance in causing NE $[17,20,21]$. It is very likely that multiple virulence factors function synergistically to induce disease.

Recombinant $\mathrm{Cp} \alpha$-toxin and NetB vaccines have been found to give partial protection against NE [1,22-26]. Owing to the differential presence and absence of toxin genes among the individual $\mathrm{Cp}$ strains used, a solution to the NE problem is still elusive $[1,14]$. Immunization of chickens against the disease is considered an alternative strategy to control NE in poultry. Killed whole cell bacterial vaccines are one of the best methods to control bacterial infections [27], but, currently, no commercial vaccines are available to control NE.

We have previously developed an efficacious, eBeam-killed, whole cell Salmonella Enteritidis vaccine [28] to protect against $S$. Enteritidis colonization and shedding in poultry. The vaccine significantly enhanced immunity in vaccinated laying hens by reducing colonization and shedding of $S$. Enteritidis when challenged with $S$. Enteritidis [29]. The eBeam-killed bacterial cells cannot multiply, they remain structurally intact, and can elicit an immune response [29-31]. eBeam technology, which can deliver highly precise eBeam doses, is in use worldwide commercially for the sterilization of single-use medical devices, food pasteurization, and other applications. This same technology can be re-purposed to inactivate large volumes of bacterial preparations to develop killed vaccines that would be effective against $\mathrm{Cp}$.

The objective of this study was to develop an eBeam-killed vaccine to control the colonization of $\mathrm{Cp}$ and NE in broiler chickens. Our hypothesis was that, if a cocktail of strains were used for a vaccine formulation, it could protect chickens from NE caused by $\mathrm{Cp}$ colonization, as the cocktail would avoid the stain-to-strain variations in protection seen in other studies. Before developing a vaccine based on a cocktail of strains, it was important to understand the efficacy of the strains individually. Therefore, in this study, we used three different $\mathrm{Cp}$ strains to understand the efficacy of individual eBeam-killed-Cp preparations. The rationale of the study was that immunizing broiler chicken embryos in ovo with eBeam-killed-CP vaccine would offer enhanced immunity against $\mathrm{Cp}$ and protect 
chickens from CP colonization from the day of hatch. The eBeam-killed vaccine approach could overcome concerns about introducing live attenuated pathogenic strains (as vaccines) into food animals, as well as eliminate the need for the use of low-dose antimicrobials in food animal production systems.

\section{Materials and Methods}

\section{1. eBeam Dose Optimization}

Bacterial isolates: The NE poultry isolates (JGS4064-Group A and cpb2 negative, net $B$ negative; JGS4104 Group A and $c p b 2$ positive, net $B$ negative) and normal flora (JGS1473-(Group A and cpb2 positive, netB negative)) of Cp strains used in this study were obtained from Glenn Songer (University of Arizona). All three strains have been characterized [32,33]. Individual cultures of each Cp strain were incubated anaerobically overnight in fluid thioglycolate broth (FTG) at $37^{\circ} \mathrm{C}$ in an anaerobic chamber (5\% hydrogen $/ 5 \%$ carbon dioxide $/ 90 \%$ nitrogen).

Determination of $\mathrm{D}_{10}$ value: Overnight cultures of $\mathrm{Cp}$ strains were aliquoted $(3 \mathrm{~mL})$ into sterile Whirl-Pak ${ }^{\circledR}$ polyethylene bags (Nasco, Fort Atkinson, WI, USA). Each bag was flattened to enable uniform eBeam dosing and then heat-sealed. Sets of three bags (replicates from an overnight culture) were exposed to multiple eBeam doses. One set was left untreated as a control. After eBeam exposure, ten-fold serial dilutions were conducted in phosphate-buffered saline PBS pH 7.4, plated onto blood agar plates, and incubated anaerobically at $37^{\circ} \mathrm{C}$ for $24 \mathrm{~h}$, after which colonies were enumerated and the number of surviving colony forming units (CFU) was calculated. The $\mathrm{D}_{10}$ value (dose required to reduce a bacterial culture by one log) for each $\mathrm{Cp}$ strain was calculated as the inverse of the slope of the regression line obtained from the inactivation curve. Regression analysis was performed in Microsoft Excel.

Vaccine preparation: All three Cp strains were grown individually, anaerobically in FTG broth overnight at $37^{\circ} \mathrm{C}$. Individually, $10 \mathrm{~mL}$ of approximately $10^{8} \mathrm{CFU} / \mathrm{mL}$ cultures was placed in plastic bags and heat-sealed, with care taken to ensure there were no air bubbles or leakage of the bags. Sample bags were then double sealed in a new plastic bag and placed inside a $95 \mathrm{kPa}$ biohazard transport bags. Samples were transported on blue ice from the laboratory to the National Center for Electron Beam Research on the Texas A\&M University campus. Total time of transport was less than $30 \mathrm{~min}$.

Electron beam treatment: Samples were subjected to eBeam treatment. Briefly, eBeam dosing was carried out using a high-energy (10 MeV), $18 \mathrm{~kW}$ linear accelerator (LINAC). The delivered dose was measured using four alanine dosimeters (BioMax, Bruker BioSpin MRI, Inc., Billerica, MA, USA) placed on the top and bottom of the packaged samples. The absorbed dose with the dosimeters was measured using an electron paramagnetic resonance (EPR) E-scan analyzer (Bruker BioSpin MRI Inc., Billerica, MA). The reported absorbed dose was the average of the four dosimeters. An extensive set of preliminary studies were performed to ensure that the sample bag configuration yielded a dose-uniformity ratio (DUR) as close to 1.0 as possible. The DUR (maximum dose divided by the minimum dose received) is an important criterion when performing irradiation experiments to ensure the dose uniformity within the sample. The cells were exposed to a target dose of $10 \mathrm{kGy}$ (kilo Grays) based on the determined $\mathrm{D}_{10}$ value for each strain. The delivered dose for each experiment was measured with the use of the Bruker E-scan analyzer. Aliquots of the irradiated $\mathrm{Cp}$ cells were stored at $4{ }^{\circ} \mathrm{C}$ until utilized for different assays to confirm inactivation, verification of membrane integrity, electron microscopic analysis, and vaccination purposes.

\subsection{Characterization of E-Beam-Killed C. perfringens Cells}

Studies were performed to verify that the eBeam-killed bacterial cells would not replicate either in vitro or in vivo. For the in vitro verification, aliquots of the irradiated cells were inoculated in FTG and blood agar plates incubated anaerobically at $37^{\circ} \mathrm{C}$ and room temperature for up to 2 weeks. For the in vivo verification, 18-day-old chicken specific-pathogen free (SPF) embryos were obtained commercially from a local commercial 
facility. The large end of all eggs was wiped with $70 \%$ ethanol and gently scored with an 18-gauge needle. Then, $100 \mu \mathrm{L}$ of eBeam-killed cells $\left(1 \times 10^{6} \mathrm{CFU}\right)$ or sham (FTG) was administered in ovo into the amnion using a $1 \mathrm{~mL}$ tuberculin syringe and a 25 -gauge needle equipped with a modified needle guard to limit all injections to a depth of $3 \mathrm{~cm}$. Following treatment injection to individual embryos, injection sites on all eggs were covered with melted paraffin using a cotton swab and transferred to a hatcher maintained at $38 \pm 0.5^{\circ} \mathrm{C}$ and 55-75\% humidity. On day-of-hatch, five chicks/treatments were placed in individual rearing pens at appropriate rearing temperatures on clean pine shaving litter material. Birds were reared in $2.4 \mathrm{~m} \times 1.2 \mathrm{~m}$ pens, allowing $0.12 \mathrm{~m}^{2}$ pen space per bird, and the chicks were maintained for 2 weeks. Diet provided was according to National Research Council's guidelines for broiler chicks with water and 55\% wheat/corn-based broiler starter diet fed ad libitum. A high wheat diet was used as high concentrations of wheat in the diet have been reported to aggravate outbreaks of NE [34]. The birds were necropsied and examined for $\mathrm{Cp}$ colonization in the small intestine by dissecting a 6-inch section of small intestine cranial to Meckel's diverticulum, placed in $10 \mathrm{~mL}$ of anaerobic FTG, stomached for $30 \mathrm{~s}$, and $0.5 \mathrm{~mL}$ of gut contents was removed and placed into $4.5 \mathrm{~mL}$ of FTG. Three 10 -fold serial dilutions were performed and plated onto blood agar plates to confirm the absence of any $\mathrm{Cp}$ colonies.

Bacterial cell membrane integrity assay: A mixture of reagent $A$ and reagent $B$ (1:1 ratio) $2 \times$ staining solution from LIVE/Dead ${ }^{\circledR}$ BacLight ${ }^{\mathrm{TM}}$ bacterial viability kit (ThermoFisher, Waltham, MA, USA) was prepared according to the manufacturer's instructions. Briefly, one hundred microliters of $2 \times$ staining solution was mixed with either $100 \mu \mathrm{L}$ eBeam-killed or non-irradiated Cp cells in a well of a 96-well plate and incubated at room temperature for $15 \mathrm{~min}$. The fluorescence intensity at a wavelength centered at about $530 \mathrm{~nm}$ (emission 1; green) and $630 \mathrm{~nm}$ (emission 2; red) for each well of the entire plate was measured using a fluorescent spectrophotometer. Five replicate wells were used for each strain. Differences in the fluorescence intensity at $530 \mathrm{~nm}$ between treatments indicated the integrity of the cell membrane.

AlamarBlue assay: The alamarBlue ${ }^{\mathrm{TM}}$ cell viability assay was performed according to the manufacturer's instructions (ThermoFisher). This assay was used to measure the metabolic activity with eBeam-treated $\mathrm{Cp}$ and non-irradiated $\mathrm{Cp}$. Briefly, resazurin is reduced to resorufin in the presence of a reducing environment, such as the case in a metabolically active bacterium. For this experiment only, $\mathrm{Cp}$ strains were grown anaerobically in reinforced clostridial medium (RCM) rather than FTG. This was done because FTG contains ingredients such as sodium thioglycolate and resazurin that interfere with assay performance. The metabolic activity was measured after eBeam treatment. Then, $90 \mu \mathrm{L}$ of each irradiated sample was added to a 96-well plate along with $10 \mu \mathrm{L}$ of $10 \times$ alamarBlue $^{\mathrm{TM}}$ reagent. Non-irradiated $\mathrm{Cp}$ was used as control. The plate was incubated in the dark at $37^{\circ} \mathrm{C}$ for $1 \mathrm{~h}$ and fluorescence was read using a plate reader at an excitation wavelength between 540 and 570 and emission wavelength between 580 and $610 \mathrm{~nm}$.

Sample preparation for scanning and transmission electron microscope analyses: Aliquots of the eBeam-irradiated and non-irradiated $\mathrm{Cp}$ cells were preserved for ultrastructural examination by mixing equal volumes of sample with a fixative containing $4 \%$ glutaraldehyde prepared in $100 \mathrm{mM}$ phosphate and $100 \mathrm{mM}$ sucrose, $\mathrm{pH}$ 7.4. After initial fixation, samples were rinsed twice in a wash buffer $(50 \mathrm{mM}$ phosphate, $50 \mathrm{mM}$ sucrose, $\mathrm{pH} 7.4$ ) by centrifugation at $1600 \times g$ for $10 \mathrm{~min}$ and resuspended in $1 \mathrm{~mL}$ of buffer. For those cells examined using SEM, a $50 \mu \mathrm{L}$ aliquot of the sample was placed on $0.1 \%$ poly-L-lysine-coated glass coverslips and incubated at room temperature for $60 \mathrm{~min}$. The sample was fixed to the coverslips by immersion in 3\% glutaraldehyde fixative for $60 \mathrm{~min}$, followed by postfixation in $1 \% \mathrm{OsO}_{4}$ prepared in $100 \mathrm{mM}$ phosphate and $100 \mathrm{mM}$ sucrose, $\mathrm{pH} 7.4$, for $90 \mathrm{~min}$ at $4{ }^{\circ} \mathrm{C}$. The coverslips were dehydrated and critical point dried in $\mathrm{CO}_{2}$. The dried samples were then sputter-coated with gold and examined in a Hitachi H7110 Scanning-Transmission Electron Microscope (STEM) (Hitachi High-Tech America, Schaumburg, IL, USA). The remaining portions of the samples were pelleted in $2.5 \%$ agar, 
postfixed in $1 \% \mathrm{OsO}_{4}$ as above, and poststained overnight in $0.5 \%$ aqueous uranyl acetate, dehydrated and embedded in Mollenhauer's mixture of epoxy resin [35]. Thin sections $(75 \mathrm{~nm})$ of embedded samples were examined in the same electron microscope as cited above operating in transmission mode.

\subsection{Embryo Vaccination}

Bird studies were performed at the USDA-Southern Plains Area Research Center in College Station under the USDA/SPARC Institutional Animal Care and Use Committee approved procedure. $\mathrm{Cobb} \times$ Ross straight run broiler embryos were obtained commercially from a local commercial facility on day 18 of embryogenesis. Eggs were candled for viability prior to placement in hatching cabinets in all experiments.

A total of 330 eggs were used for this study; Table 1 (six groups: negative control, positive control, challenge-eyes control, eBeam JGS4064, eBeam JGS1473, and eBeam JGS4104). Each treatment group contained 55 embryos (5 extra embryos were included to account for variation in hatchability), but after hatch, only 50 birds were maintained (25 birds for early-challenge and 25 birds for late-challenge). Embryo vaccination was explained earlier under Section 2.2. Characterization of E-beam-killed C. perfringens cells. Out of 25 birds, blood was collected from 15 birds and 10 birds were used for bacterial colonization analysis. All 25 birds were used for lesion scoring and weight sampling. Individual groups were placed in separate hatching trays after vaccination and placed to hatch in the same hatching cabinet to provide identical hatching conditions. On dayof-hatch, the chicks hatched in each treatment group were further divided equally into two groups (early and late challenge) and placed in individual rearing pens on clean pine shaving litter material at appropriate rearing temperatures. Positive and negative control birds were kept in individual rooms separate from the other groups. A commercial bursal disease vaccine (Bursa-Vac, Merck Animal Health, Summit, NJ, USA) was administered to birds at $10 \times$ the recommended dose via the ocular route at day 18 for early-challenge and day 25 for late-challenge to immunocompromise the birds and aid in the development of NE [36]. Birds were challenged with the individual strains once daily by oral gavage ( $3 \mathrm{~mL}$ per bird) with a stock culture of $1 \times 10^{7} \mathrm{CFU}$ of $\mathrm{Cp} / \mathrm{mL}$ for 3 consecutive days, beginning on day 18 for early-challenge and day 25 for late-challenge. Positive control birds were challenged with a mixture of all three strains of $\mathrm{Cp}\left(1 \times 10^{7} \mathrm{CFU}\right)$. The birds were necropsied on day 22 for early-challenge and day 29 for late-challenge by cervical dislocation and examined for $\mathrm{Cp}$ colonization in the ileum by dissecting a 6-inch section of ileum, placed in $10 \mathrm{~mL}$ of anaerobic FTG, stomached for $30 \mathrm{~s}$, and $0.5 \mathrm{~mL}$ of gut contents were removed and placed into $4.5 \mathrm{~mL}$ of FTG. Three 10 -fold serial dilutions were performed and plated onto Shahidi-Ferguson-perfringens (SFP) agar to count the vegetative cells of $\mathrm{Cp}$ colonies and the plates were incubated in an anaerobic chamber at $37^{\circ} \mathrm{C}$. Blood sample (1 to $2 \mathrm{~mL}$ ) was drawn from the vein of chickens and transferred to Vacutainer ${ }^{\circledR}$ plastic tubes to collect serum. 
Table 1. Experimental design. FTG, fluid thioglycolate broth.

\begin{tabular}{|c|c|c|c|c|c|}
\hline \multirow[b]{2}{*}{ Group } & \multirow[b]{2}{*}{ Treatment Groups } & \multirow[b]{2}{*}{ In ovo } & \multirow[b]{2}{*}{ Challenge } & \multicolumn{2}{|c|}{ Number of Birds } \\
\hline & & & & $\begin{array}{c}\text { Early- } \\
\text { Challenge }\end{array}$ & $\begin{array}{c}\text { Late- } \\
\text { Challenge }\end{array}$ \\
\hline 1 & Neg Control & FTG medium & No challenge & 25 & 25 \\
\hline 2 & Positive Control & FTG medium & $\begin{array}{c}\text { JGS4064, JGS4104, } \\
\text { JGS1473 }\end{array}$ & 25 & 25 \\
\hline 3 & Challenge-Eyes & FTG medium & Bursa-Vac & 25 & 25 \\
\hline 4 & eBeam killed JGS4064 & vaccine & JGS4064 & 25 & 25 \\
\hline 5 & E-Beam killed JGS4104 & vaccine & JGS4104 & 25 & 25 \\
\hline 6 & E-Beam killed JGS1473 & vaccine & JGS1473 & 25 & 25 \\
\hline
\end{tabular}

\subsection{Measurement of $\operatorname{Ig} Y$ Antibody Titers}

The titer of total serum IgY antibodies was measured with the use of direct enzymelinked immunosorbent assay (ELISA). Briefly, wells of ninety-six-well polystyrene microtiter plates were coated with $100 \mu \mathrm{L}$ of respective $\mathrm{Cp}$ strain, diluted in coating buffer (50 mM carbonic acid buffer, $\mathrm{pH}$ 9.6), and incubated at $4{ }^{\circ} \mathrm{C}$ overnight. The plates were blocked with $200 \mu \mathrm{L}$ of PBS-T containing $5 \%$ skim milk at $4{ }^{\circ} \mathrm{C}$ overnight. Sera from 15 birds were pooled from each treatment group and diluted 1:10,000 with coating buffer, and $100 \mu \mathrm{L}$ of each pool was added in triplicate to a 96-well and incubated for $3 \mathrm{~h}$ at room temperature, and then washed three times with PBS-T. One hundred microliters of rabbit anti-chicken IgY-HRP antibody (Invitrogen) diluted 1:4000 with blocking buffer was added to each well and incubated for $1 \mathrm{~h}$ at $37^{\circ} \mathrm{C}$. After incubation at $37^{\circ} \mathrm{C}$ for $1 \mathrm{~h}$, the plates were washed three times with PBS-T, followed by the addition of $100 \mu \mathrm{L}$ of $o$-phenylenediamine dihydrochloride (OPD)/well $\left(1 \mathrm{mg} / \mathrm{mL}\right.$ : made with SIGMAFAST ${ }^{\mathrm{TM}}$ OPD two-tablet sets) for the detection of bound IgY. The optical density (OD) at $450 \mathrm{~nm}$ of each well was measured using the Wallac Victor 1420 Multilabel counter (Perkin Elmer, Boston, MA, USA). The OD values were recorded as the mean of triplicate wells.

Pre-challenge sera samples were obtained on day 18 for early-challenge and day 25 for late-challenge chicks that had been immunized with specific strains of eBeam-killed $\mathrm{Cp}$ vaccine on 18-day-old embryogenesis and non-immunized birds (negative and positive control). The post-challenge sera samples were obtained on day 22 for early-challenge and day 29 for late-challenge from immunized and non-immunized positive and negative control (no challenge) chicks. Chicks in all groups except negative control were challenged with a respective strain of $C p$ for three consecutive days $(18,19$, and 20 for early-challenge, and 25,26 , and 27 for late-challenge), but the positive control was challenged with a mixture of all three strains. The chicks in both negative and positive control were not immunized with eBeam-killed $\mathrm{Cp}$ vaccine. The chicks in the negative control group were neither immunized nor challenged with $\mathrm{Cp}$.

\subsection{Statistical Analyses}

Differences in the antibody response between vaccinated and unvaccinated groups were analyzed by one-way analysis of variance (ANOVA) (GraphPad Prism, San Diego, CA, USA). Differences in the amount of recovered $C p$ between vaccinated and unvaccinated groups were analyzed by one-way ANOVA (GraphPad Prism). A $p$-value less than 0.05 was statistically significant.

\section{Results and Discussion}

\subsection{Characterization of E-Beam-Irradiated C. perfringens Cells}

The $\mathrm{D}_{10}$ value of the individual strains was calculated to be between $0.83 \mathrm{kGy}$ and 1.14 kGy (JGS1473: 1.14 kGy; JGS4104: 0.83 kGy; JGS4064: 0.98 kGy). Based on these values and because the typical titer of an overnight culture is approximately $10^{8} \mathrm{CFU} / \mathrm{mL}$, a $10 \mathrm{kGy}$ eBeam dose was chosen to inactivate $\mathrm{Cp}$ for the killed vaccine preparation. A sim- 
ilar fluorescence measurement in both LIVE/Dead ${ }^{\circledR}$ BacLight $^{\mathrm{TM}}$-stained eBeam-killed-Cp and untreated control Cp cells confirmed that the $10 \mathrm{kGy}$ dose did not cause any damage to the cell membrane of eBeam-irradiated cells (Figure 1). The AlamarBlue assay was performed to check the viability and metabolic activity of the eBeam-killed-Cp cells. The results indicate that there were no differences in metabolic activity between eBeam-killed-Cp cells and (no eBeam treatment control) live Cp immediately after treatment $(p>0.05)$ (Figure 2).

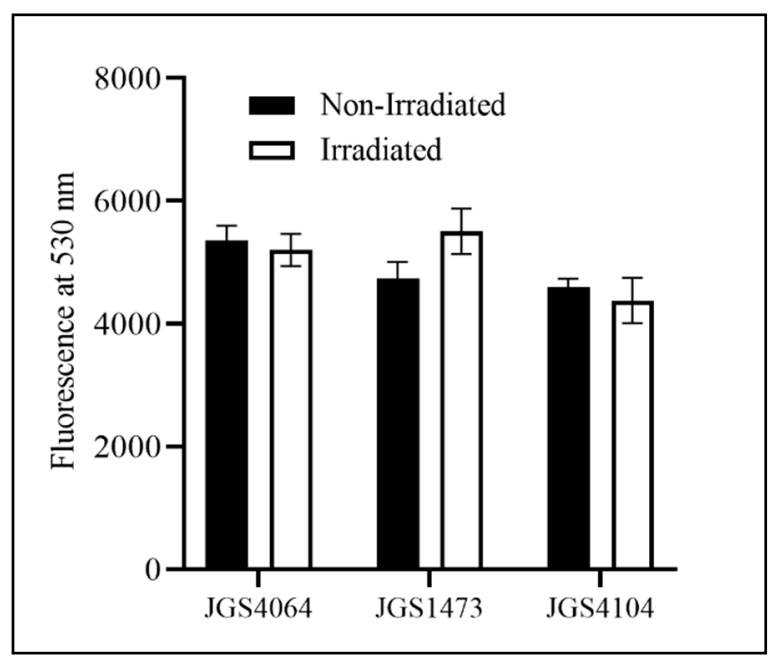

Figure 1. Fluorescence measured at $530 \mathrm{~nm}$ for eBeam-killed and non-irradiated (live cells) of three strains of Clostridium perfringens (JGS4064, JGS1473, and JGS4104) stained with BacLight ${ }^{\mathrm{TM}}$ to determine the bacterial viability and cell wall integrity. Dark bar-non-irradiated CP cells; white bar-eBeam-killed CP cells (irradiated).

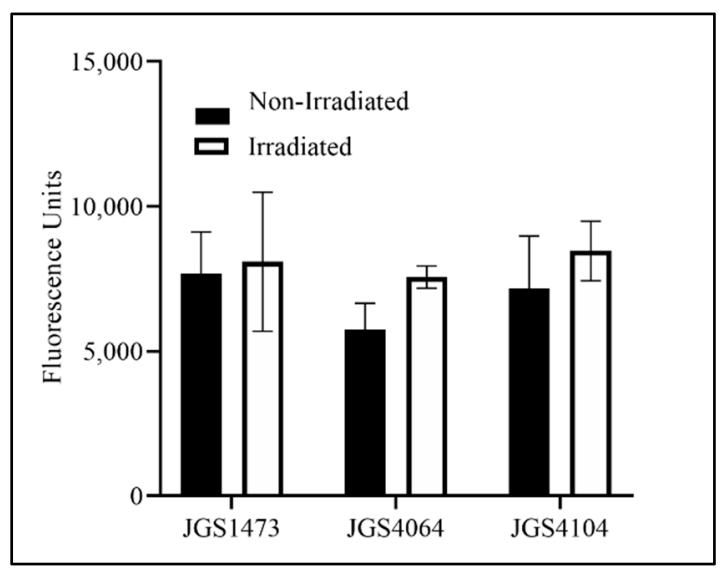

Figure 2. Fluorescence recorded for eBeam-killed and non-irradiated (live cells) of three strains of Clostridium perfringens (JGS4064, JGS1473, and JGS 4104) stained with alamarBlue ${ }^{\mathrm{TM}}$ to determine the metabolic activity. Dark bar-non-irradiated CP cells; white bar-eBeam-killed CP cells (irradiated).

The ultrastructure examination of Cp strains under TEM and SEM revealed that there were no discernable differences in any of these isolates after eBeam exposure. The strains exhibited a range of morphologies that was consistent between the control and eBeam irradiated samples within a strain, but different between strains (Figure 3). Strain JGS4064 was observed as individual rods (Figure 3A-D), and strains JGS1473 and JGS4104 were observed as long chains of rods (Figure 3E-L). Bacterial spores were only observed in the control sample from isolate JGS4064 (Figure 3C). We have shown in this study that, when eBeam irradiation is performed at $10 \mathrm{kGy}$, there is no visible damage to the Cp cell membrane (Figure 3 ). This confirms that ionizing radiation mainly causes damages to 
nucleic acid [29,30]. The uniqueness of eBeam-based inactivation is that a vaccine can be developed where, even though the nucleic acid is shredded (preventive cell multiplication), the structural integrity of the bacterium ensures that there is little if any collateral damage to the cell membrane (Figure 3), thereby retaining the surface antigens/epitopes. Therefore, eBeam-killed vaccines have the safety of a killed vaccine yet retain the immunogenic potential of a live vaccine.
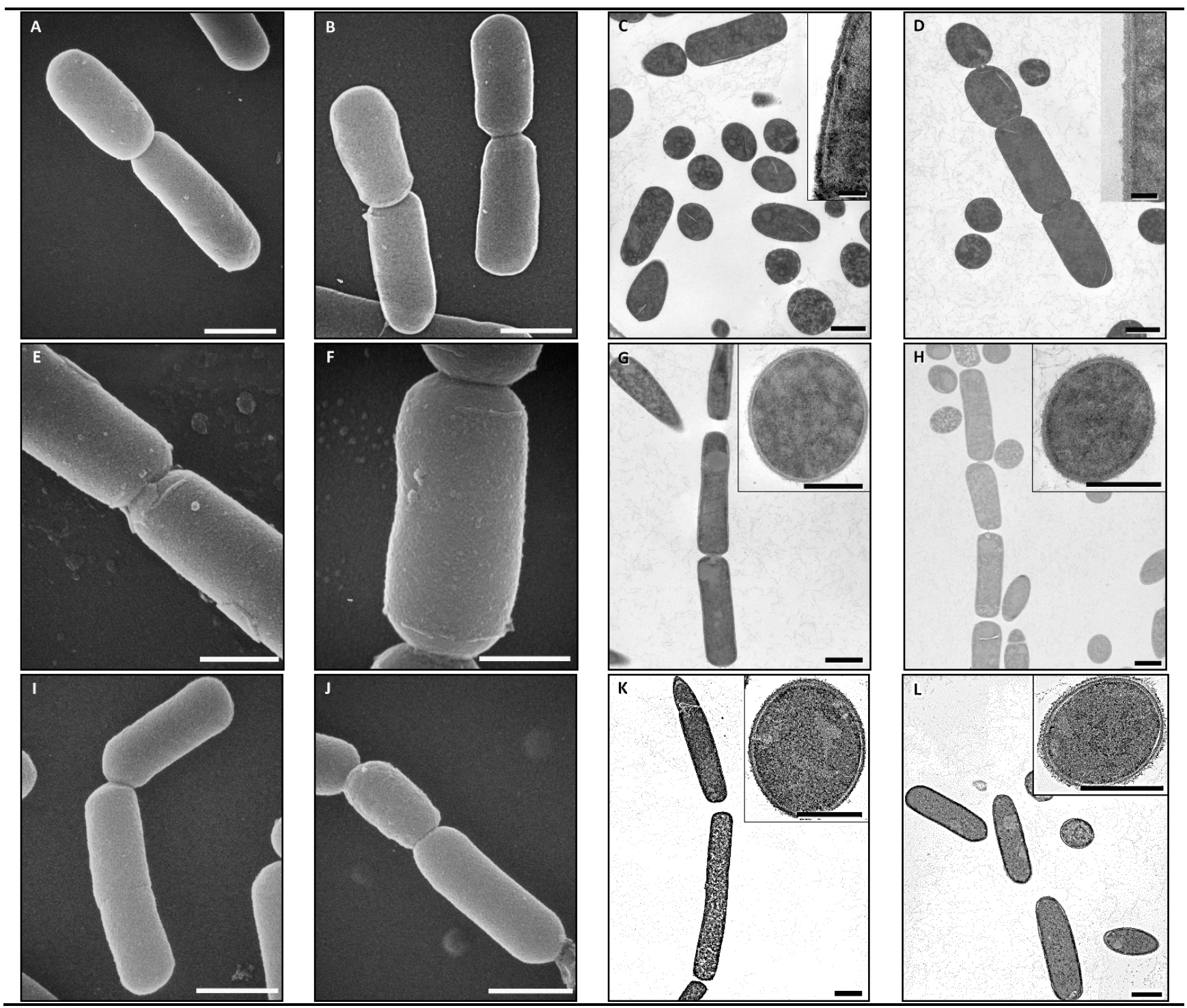

Figure 3. Scanning electron microscope (SEM) and transmission electron microscope (TEM) images of non-irradiated and eBeam-killed C. perfringens cells: (A) SEM of non-irradiated JSG4064 (bar = $1.0 \mu \mathrm{m}$ ); (B) SEM of eBeam-killed JSG4064 (bar $=1.0 \mu \mathrm{m}$ ); (C) TEM of non-irradiated JSG4064 (background bar = $1.0 \mu \mathrm{m}$; inset bar = $0.1 \mu \mathrm{m}$ ); (D) TEM of eBeam-killed JSG4064 (background bar = $1.0 \mu \mathrm{m}$; inset bar = 0.1 $\mu \mathrm{m})$; (E) SEM of non-irradiated JSG1473 $($ bar $=0.5 \mu \mathrm{m}) ;($ F) SEM of eBeam-killed JSG1473 (bar = $0.5 \mu \mathrm{m})$; $(\mathrm{G})$ TEM of non-irradiated JSG1473 (background bar $=1.0 \mu \mathrm{m}$; inset bar $=0.5 \mu \mathrm{m}$ ); (H) TEM of eBeam-killed JSG1473 (background bar $=1.0 \mu \mathrm{m}$; inset bar $=0.5 \mu \mathrm{m}$ ); (I) SEM of non-irradiated JSG4104 (bar = $1.0 \mu \mathrm{m})$; (J) SEM of eBeam-killed JSG4104 (bar = $1.0 \mu \mathrm{m}) ;(\mathrm{K})$ TEM of non-irradiated JSG4104 (background bar $=1.0 \mu \mathrm{m}$; inset bar $=0.5 \mu \mathrm{m})$; (L) TEM of eBeam-killed JSG4104 (background bar $=1.0 \mu \mathrm{m}$; inset bar $=0.5 \mu \mathrm{m}$ ).

The eBeam-treated Cp cells did not multiply in either FTG broth or blood agar plates when incubated overnight anaerobically at $37^{\circ} \mathrm{C}$, or when incubated anaerobically at room temperature for up to 4 weeks. This suggested that the cells were lethally inactivated, preventing their multiplication even in favorable, nutrient-rich conditions. The enriched 
cecal contents from 2-week-old chicks that hatched from chicken SPF embryos inoculated with eBeam-irradiated $\mathrm{Cp}$ cells were also negative for $\mathrm{Cp}$ colonies. Both in vitro and in vivo attempts to resuscitate the eBeam-killed-Cp were unsuccessful, confirming that the $10 \mathrm{kGy}$ eBeam dose used in this study killed the high titer $\left(10^{8} \mathrm{CFU} / \mathrm{mL}\right)$ of bacteria in the vaccine preparation.

\subsection{Protection against $C$. perfringens Colonization in Broiler Chickens}

We did not observe any major clinical signs, morbidity, death, or weight loss in either the vaccinated or the unvaccinated birds (Table 2 ). It is widely known that obtaining gross lesion of NE consistently is a challenge under experimental conditions [37,38]. Moreover, the absence of clinical signs may be because of the absence of Eimeria in this study. Other studies have shown that co-infection of Eimeria species with Cp induced NE [39-43]. The ileal content of birds in the non-vaccinated and non-challenged negative control in the early-challenge were negative for Cp (Figure 4a), but one bird in the late-challenge was positive (Figure $4 \mathrm{~b}$ ). The colonization of $\mathrm{Cp}$ in negative control group of the latechallenge may be from the environment. The birds in the positive control (non-vaccinated, but challenged with $\mathrm{Cp}$ ) had a higher burden of $\mathrm{Cp}$ in the late-challenge (mean of $\mathrm{Cp}$ $5.2 \pm 0.5 \log _{10} \mathrm{CFU} / \mathrm{g}$ ) than the early-challenge (mean of Cp $2.8 \pm 0.9$ ); Figure 4a,b. Only $5 / 10$ birds had $\mathrm{Cp}$ colonization in the early-challenge (Figure $4 \mathrm{a})$, whereas all birds (10/10) were colonized with $C p$ in the late-challenge (Figure $4 b)$. Though the birds in the positive control group were immunosuppressed via BursaVac and challenged with $\mathrm{Cp}$ for three consecutive days, only 50\% of birds were positive for Cp in early-challenge, while $100 \%$ of the late-challenge group were positive for colonization. The reason for lower colonization in the early-challenge is unknown.

Table 2. (a) Response of birds to early-challenge with various C. perfringens (CP) strains. (b) Response of birds to late-challenge with various $C$. perfringens $(\mathrm{CP})$ strains.

\begin{tabular}{|c|c|c|c|}
\hline \multicolumn{4}{|c|}{ (a) } \\
\hline Treatment & $\begin{array}{c}\text { Birds with Gross } \\
\text { Lesions/Total Birds } \\
(\%)\end{array}$ & $\begin{array}{c}\text { Average Lesion } \\
\text { Score }\end{array}$ & $\begin{array}{c}\text { Average Weight of } \\
\text { Birds before } \\
\text { Necropsy (kg) }\end{array}$ \\
\hline JGS1473 & $1 / 25(4)$ & 0.08 & 0.76 \\
\hline JGS 4064 & $2 / 25(8)$ & 0.08 & 0.75 \\
\hline JGS 4104 & $3 / 25(12)$ & 0.12 & 0.79 \\
\hline Positive control & $11 / 25(44)$ & 0.6 & 0.81 \\
\hline Negative control & $0 / 25(0)$ & 0 & 0.84 \\
\hline \multicolumn{4}{|c|}{ (b) } \\
\hline Treatment & $\begin{array}{c}\text { Birds with Gross } \\
\text { Lesions/Total Birds } \\
(\%)\end{array}$ & $\begin{array}{l}\text { Average Lesion } \\
\text { Score }\end{array}$ & $\begin{array}{l}\text { Average Weight of } \\
\text { Birds before } \\
\text { Necropsy (kg) }\end{array}$ \\
\hline JGS1473 & $4 / 25(16)$ & 0.16 & 1.22 \\
\hline JGS 4064 & $4 / 25(16)$ & 0.16 & 1.23 \\
\hline JGS 4104 & $3 / 25(12)$ & 0.12 & 1.26 \\
\hline Positive control & $6 / 25(24)$ & 0.28 & 1.24 \\
\hline Negative control & $1 / 25(4)$ & 0.04 & 1.23 \\
\hline
\end{tabular}




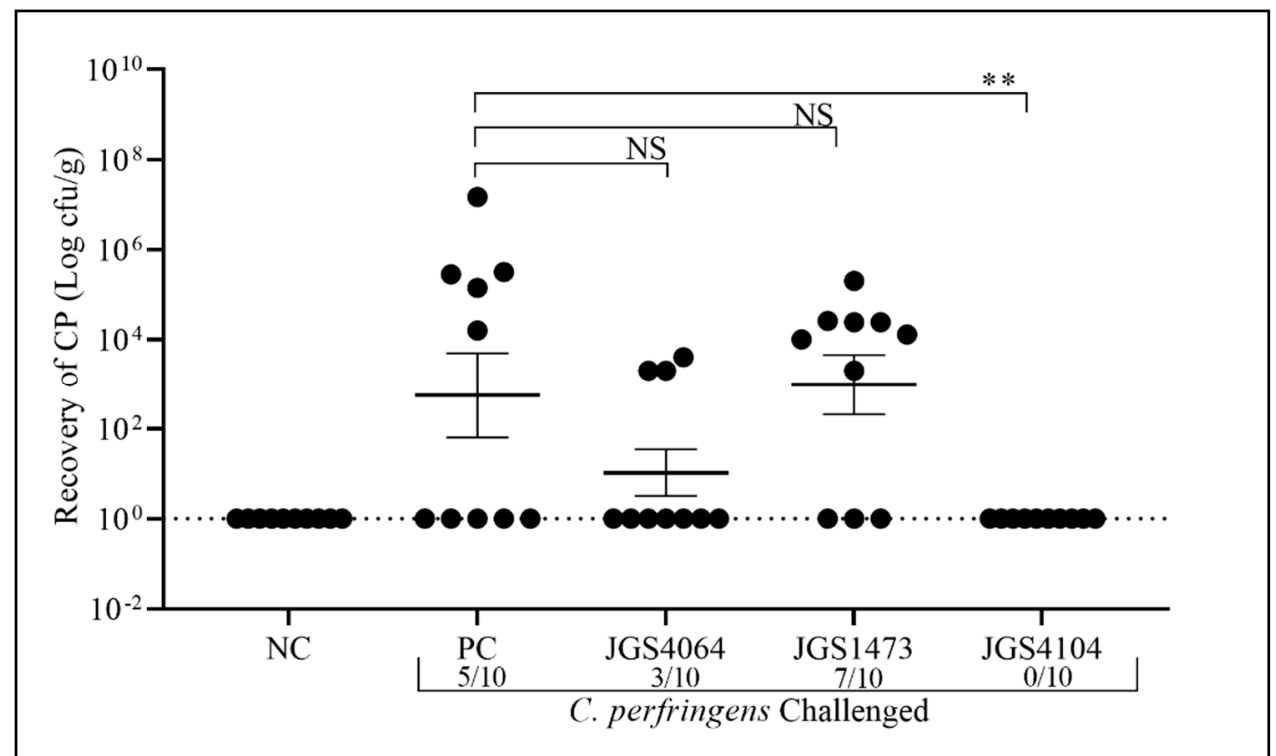

(a)

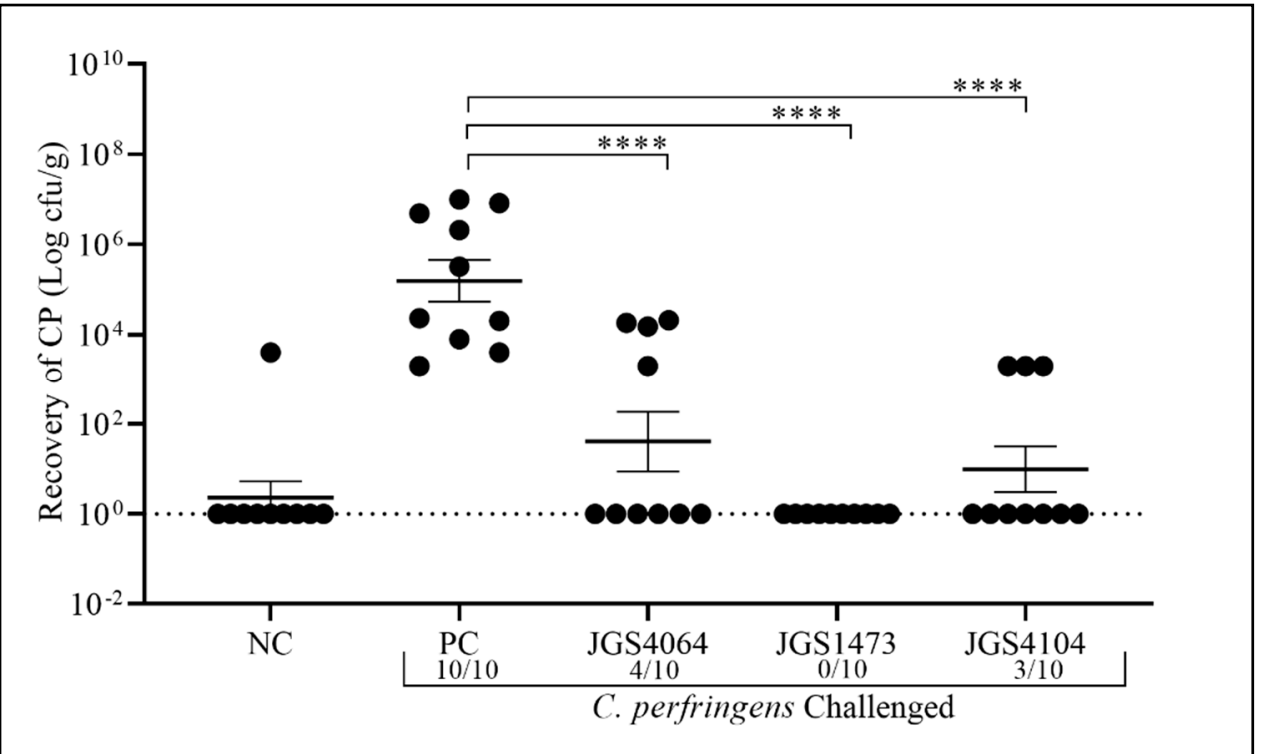

(b)

Figure 4. Prevention of $C$. perfringens $(\mathrm{CP})$ colonization by eBeam-killed vaccine as determined by bacterial counts in ileal contents. Birds in all groups were inoculated with $1 \times 10^{7} \mathrm{CFU}$ of $\mathrm{CP}$ via oral gavage. Horizontal bar represents mean \pm standard error. Birds were necropsied four days after post-challenge (day 22 for early-challenge and day 29 for late-challenge), and C. perfringens counts in ileal contents were determined ( $n=10$ in each groups). Significant difference in values, ${ }^{* *} p<0.01$ and ${ }^{* * *} p<0.0001$, was determined by one-way analysis of variance (ANOVA) and NS = not significant. $\mathrm{PC}=$ Positive control; NC = Negative control. (a) Early challenge and (b) late challenge.

Among birds immunized with eBeam-killed JGS4064, 30\% (3 out of 10 birds) in the early-challenge (Figure $4 \mathrm{a}$ ) and $40 \%$ ( 4 birds out of 10) in the late-challenge (Figure $4 \mathrm{~b}$ ) were positive for $\mathrm{Cp}$ colonization, indicating $70 \%$ and $60 \%$ protection, respectively. The mean $\mathrm{Cp}$ counts in the eBeam-killed-JGS4064 immunized birds in each challenge were lower than the positive control (early-challenge: $1.0 \pm 0.5$ and late-challenge: $1.6 \pm 0.7 \log _{10} \mathrm{CFU} / \mathrm{g}$ ), but statistically not significant in the early-challenge (Figure 4a). The lack of statistical significance in the early challenge group when compared with the positive control group is likely due to a low number of $\mathrm{Cp}$-positive birds in the positive control group. The latechallenge had a significantly $\left(1.6 \pm 0.7 \log _{10} \mathrm{CFU} / \mathrm{g}, p<0.006\right)$ reduced number of $\mathrm{Cp}$ in the positive birds (Figure $4 \mathrm{~b}$ ). 
Among birds immunized with eBeam-killed-JGS1473, 70\% (7 out of 10 birds) in the early-challenge (Figure $4 \mathrm{a}$ ) and $0 \%$ (0 birds out of 10 birds) in the late-challenge (Figure $4 \mathrm{~b}$ ) were positive for $\mathrm{Cp}$ colonization, indicating 30\% and 100\% protection, respectively. The mean Cp counts in the eBeam-killed-JGS1473 immunized birds of early-challenge were higher $\left(2.98 \pm 0.67 \log _{10} \mathrm{CFU} / \mathrm{g}\right)$ than the positive control, but not statistically significant (Figure $4 \mathrm{a})$, whereas Cp colonization in the late-challenge was significantly $(p<0.0001)$ reduced (0 $\left.\log _{10} \mathrm{CFU} / \mathrm{g}\right)$ (Figure $\left.4 \mathrm{~b}\right)$.

Among birds immunized with eBeam-killed-JGS4104, 0\% (0 out of 10 birds) in the early-challenge (Figure $4 \mathrm{a}$ ) and 30\% (3 out of 10 birds) in the late-challenge (Figure $4 \mathrm{~b}$ ) were positive for $\mathrm{Cp}$ colonization, indicating $100 \%$ and $70 \%$ protection, respectively. The mean Cp counts in the eBeam-killed-JGS4104 immunized birds in each challenge were lower than the positive control in both challenges and statistically significant (Figure $4 a, b)$ in the early-challenge $\left(0 \log _{10} \mathrm{CFU} / \mathrm{g}, p<0.004\right)$ and late-challenge $\left(0.99 \pm 0.5 \log _{10} \mathrm{CFU} / \mathrm{g}\right.$, $p<0.001)$, respectively. The reason for the presence of three $\mathrm{Cp}$ positive birds in the late-challenge could be the colonization of non-vaccine strains from the environment.

All three strains used in the study provided protection when challenged with the homologous strains, except Cp JGS1473. In this strain, birds were less protected in the early challenge, but showed $100 \%$ protection in the late challenge. This may indicate that the immune response of this strain is delayed when compared with the other strains used in this study. Interestingly, JGS1473 was initially isolated from the microflora of a healthy bird, while JGS4104 and JGS40164 were isolated from a turkey and chicken with $\mathrm{NE}$, respectively [32].

The serum IgY level was significantly $(p<0.0001)$ lower in both the negative control (unvaccinated and unchallenged) and positive control (unvaccinated, but challenged) birds when compared with the birds immunized with individual eBeam-killed vaccine (Figure 5a,b). In general, higher IgY levels were observed in the post-challenged birds in all three immunized groups than in the negative and positive control. IgY levels were significantly higher after challenge in all groups. Furthermore, IgY levels in birds in the late-challenge group had higher IgY than in the early-challenge group (Figure 5a,b). The increased protection against $\mathrm{Cp}$ colonization (Figure $4 \mathrm{~b}$ ) in all three immunized groups and in later challenged groups could be due to the presence of elevated levels of IgY (Figure 5b).

We had previously developed an eBeam-killed vaccine against $S$. Enteritidis [29]. We obtained similar results of reduced colonization of $S$. Enteritidis in the vaccinated birds. We had also observed that the eBeam-killed vaccine is antigenic and induces innate immunity [44]. Other bacterial vaccines (Brucella melitensis, Listeria monocytogenes, Rodentibacter pneumotropicus, Staphylococcus aureus, and Streptococcus pneumoniae) developed using ionizing radiation showed higher humoral immune responses and protection against bacterial infection in humans and animals [31,45-51]. Whole cells inactivated vaccines have been shown to provide cross protective immunity against other strains $[52,53]$. Though the $\mathrm{Cp}$ challenge in this study did not produce clinical signs for NE, the eBeam-killed vaccine reduced the colonization of $\mathrm{Cp}$ compared with the non-vaccinated control, suggesting that eBeam technology could be a good tool to kill/inactivate the bacterial pathogen without damaging the epitopes. As each $\mathrm{Cp}$ strain produces a variety of toxins, vaccinating birds with an individual strain might not protect against other strains. Moreover, $\mathrm{Cp}$ strains can also transfer their plasmids by horizontal gene transfer, thereby converting non-pathogenic strains to pathogenic strains [54]. It is critically important to perform further studies to understand the mechanism of vaccine protection, test cross protection abilities, as well as use a mixture of virulent strains in the vaccine preparation. As C $\mathrm{p}$ is not only a poultry pathogen, but also considered as a foodborne pathogen that causes foodborne illnesses in the United States and other countries $[55,56]$, controlling Cp in broiler chickens by vaccination will not only reduce the economic loss, but also reduce human foodborne illnesses. 


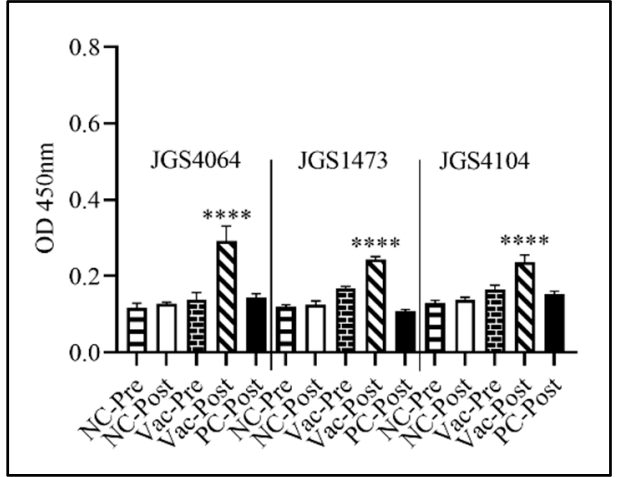

(a)

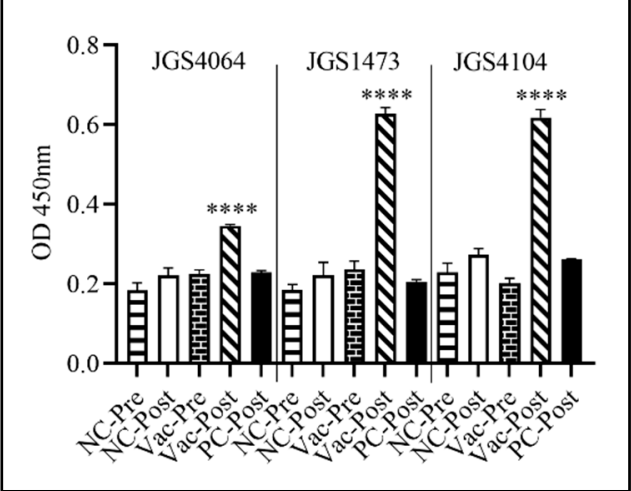

(b)

Figure 5. IgY response to CP strains: JSG4064, JSG1473, and JSG4104 using enzyme-linked immunosorbent assay (ELISA). Day 18 chicken embryos were immunized in ovo with either eBeamkilled-JSG4064, eBeam-killed-JSG1473, or eBeam-killed-JSG4104. Pre-challenge sera were collected on day 18 for early-challenge and day 25 for late-challenge. Post-challenge sera were collected on day 22 for early-challenge and day 29 for late-challenge. Each bar represents mean \pm SEM. Asterisks indicate a statistically significant difference relative to the post-challenge positive control birds $(* * * * p<0.0001)$ determined by one-way ANOVA. OD = optical density (a) Early challenge and (b) late challenge.

The benefits of developing vaccines using eBeam technology are that it is chemicalfree, highly scalable, and can be very precise in delivering the eBeam doses as well as assure complete inactivation of large volume lots. Presently, several irradiated viral and bacterial vaccines have been developed that have been shown to be more efficacious than other vaccines prepared by other technologies [57-62]. Electron beam technology platforms are continually improving in terms of robustness, modularity, and versatility in terms of beam power and electron energies [63]. Another major advantage of eBeam-killed vaccines is that their potency can be maintained for extended periods of time. We have recently reported that, even after 30 days at room temperature, the immunoreactivity profile of eBeam-inactivated Salmonella Typhimurium was very similar to that of live, unexposed Salmonella Typhimurium [64]. The cost of implementing this technology for the veterinary industry will depend on the operating costs and the amortized capital costs [63]. However, low-energy eBeam dosing systems are already in development and have been demonstrated to be suitable for developing viral vaccines [52]. Once low-energy eBeam and similar technologies are commercially available, the costs of this technology per unit vaccine dose would become clearer.

\section{Conclusions}

Vaccination is the preferred alternative to control Cp colonization in broiler chickens than antibiotics mixed infeed/water. Vaccines have been used to successfully control clostridial diseases in livestock animals [62]. In this study, we have developed killed Cp 
vaccines using eBeam technology against three individual $C p$ strains. The vaccines were delivered in ovo to day 18 embryos and good protection against colonization of $\mathrm{Cp}$ in early and late challenge was observed, except for one strain (JGS1473), which had lower protection in the early challenge. Though we did not find significant clinical signs for NE, the vaccine significantly reduced the colonization of $C p$ (Figure $5 a, b)$. The advantage of using an eBeam-killed vaccine is that it reduces the potential risk of pathogen survival within the poultry houses and posing a threat to both humans and subsequently a lot of birds. Overall, the above-described approach to prevent $\mathrm{Cp}$ colonization in chickens can be potentially paradigm-shifting in terms of ability to quick develop vaccines against prevailing strains and the ability to rapidly scale the inactivation step.

Author Contributions: P.R.J. and S.D.P. designed the study; P.R.J., S.S.B., K.K.S., C.P., K.J.G., H.L.H., J.L.M., J.A.B., C.L.S., and M.H.K. performed the experiment and analyzed the data; R.D. performed electron microscopic study and analysis; D.J.N. supervised the study; P.R.J. and S.S.B. wrote the original draft. All authors have read and agreed to the published version of the manuscript.

Funding: This work was supported by the USDA-NIFI as part of the Hatch Grant H8708 administered by Texas A\&M AgriLife Research. This work was performed as part of the IAEA Collaborating Centre activities.

Institutional Review Board Statement: Bird studies were performed at the USDA-Southern Plains Area Research Center in College Station, Texas under the USDA/SPARC Institutional Animal Care and Use Committee approved procedure (2009005).

Data Availability Statement: This study did not report any data.

Acknowledgments: The USDA is an equal opportunity provider and employer. Mention of trade names or commercial products in this publication is solely for the purpose of providing specific information and does not imply recommendation or endorsement by the USDA.

Conflicts of Interest: The authors declare no conflict of interest. The author associated with Church \& Dwight Co. Inc was involved in this project during his earlier affiliation with the USDA-ARS.

\section{References}

1. Cooper, K.K.; Songer, J.G. Necrotic enteritis in chickens: A paradigm of enteric infection by Clostridium perfringens type A. Anaerobe 2009, 15, 55-60. [CrossRef]

2. Porter, R.E., Jr. Bacterial enteritides of poultry. Poult. Sci. 1998, 77, 1159-1165. [CrossRef] [PubMed]

3. Moore, R.J. Necrotic enteritis predisposing factors in broiler chickens. Avian Pathol. 2016, 45, 275-281. [CrossRef] [PubMed]

4. Al-Sheikhly, F.; Truscott, R.B. The pathology of necrotic enteritis of chickens following infusion of crude toxins of Clostridium perfringens into the duodenum. Avian Dis. 1977, 21, 241-255. [CrossRef] [PubMed]

5. Wade, B.; Keyburn, A. The True Cost of Necrotic Enteritis is Huge; World Poultry: Doetinchem, The Netherlands, $2015 ;$ p. 5.

6. Batz, M.; Hoffmann, S.; Morris, J.G., Jr. Disease-outcome trees, EQ-5D scores, and estimated annual losses of quality-adjusted life years (QALYs) for 14 foodborne pathogens in the United States. Foodborne Pathog. Dis. 2014, 11, 395-402. [CrossRef]

7. Ficken, M.D.; Wages, D.P. Necrotic Enteritis, Diseases of Poultry, 10th ed.; Calnek, B.W., Barnes, H.J., Beard, C.W., McDougald, L.R., Saif, Y.M., Eds.; Mosby-Wolfe: Ames, IA, USA, 1997.

8. Wierup, M. The Swedish experience of the 1986 year ban of antimicrobial growth promoters, with special reference to animal health, disease prevention, productivity, and usage of antimicrobials. Microb. Drug Resist. 2001, 7, 183-190. [CrossRef]

9. Thompson, D.R.; Parreira, V.R.; Kulkarni, R.R.; Prescott, J.F. Live attenuated vaccine-based control of necrotic enteritis of broiler chickens. Vet. Microbiol. 2006, 113, 25-34. [CrossRef]

10. Hermans, P.G.; Morgan, K.L. Prevalence and associated risk factors of necrotic enteritis on broiler farms in the United Kingdom; a cross-sectional survey. Avian Pathol. 2007, 36, 43-51. [CrossRef]

11. Van Immerseel, F.; De Buck, J.; Pasmans, F.; Huyghebaert, G.; Haesebrouck, F.; Ducatelle, R. Clostridium perfringens in poultry: An emerging threat for animal and public health. Avian Pathol. 2004, 33, 537-549. [CrossRef]

12. Van Immerseel, F.; Rood, J.I.; Moore, R.J.; Titball, R.W. Rethinking our understanding of the pathogenesis of necrotic enteritis in chickens. Trends Microbiol. 2009, 17, 32-36. [CrossRef]

13. McDonel, J.L. Clostridium perfringens toxins (type A, B, C, D, E). Pharmacol. Ther. 1980, 10, 617-655. [CrossRef]

14. Rood, J.I.; Adams, V.; Lacey, J.; Lyras, D.; McClane, B.A.; Melville, S.B.; Moore, R.J.; Popoff, M.R.; Sarker, M.R.; Songer, J.G.; et al. Expansion of the Clostridium perfringens toxin-based typing scheme. Anaerobe 2018, 53, 5-10. [CrossRef]

15. Keyburn, A.L.; Boyce, J.D.; Vaz, P.; Bannam, T.L.; Ford, M.E.; Parker, D.; Di Rubbo, A.; Rood, J.I.; Moore, R.J. NetB, a new toxin that is associated with avian necrotic enteritis caused by Clostridium perfringens. PLoS Pathog. 2008, 4, e26. [CrossRef] 
16. Keyburn, A.L.; Sheedy, S.A.; Ford, M.E.; Williamson, M.M.; Awad, M.M.; Rood, J.I.; Moore, R.J. Alpha-toxin of Clostridium perfringens is not an essential virulence factor in necrotic enteritis in chickens. Infect. Immun. 2006, 74, 6496-6500. [CrossRef]

17. Rood, J.I.; Keyburn, A.L.; Moore, R.J. NetB and necrotic enteritis: The hole movable story. Avian Pathol. 2016, 45, $295-301$. [CrossRef] [PubMed]

18. Coursodon, C.F.; Glock, R.D.; Moore, K.L.; Cooper, K.K.; Songer, J.G. TpeL-producing strains of Clostridium perfringens type A are highly virulent for broiler chicks. Anaerobe 2012, 18, 117-121. [CrossRef]

19. Prescott, J.F.; Smyth, J.A.; Shojadoost, B.; Vince, A. Experimental reproduction of necrotic enteritis in chickens: A review. Avian Pathol. 2016, 45, 317-322. [CrossRef] [PubMed]

20. Bailey, M.A.; Macklin, K.S.; Krehling, J.T. Low Prevalence of netB and tpeL in Historical Clostridium perfringens Isolates from Broiler Farms in Alabama. Avian Dis. 2015, 59, 46-51. [CrossRef] [PubMed]

21. Yang, W.Y.; Chou, C.H.; Wang, C. Characterization of toxin genes and quantitative analysis of netB in necrotic enteritis (NE)producing and non-NE-producing Clostridium perfringens isolated from chickens. Anaerobe 2018, 54, 115-120. [CrossRef]

22. Cooper, K.K.; Trinh, H.T.; Songer, J.G. Immunization with recombinant alpha toxin partially protects broiler chicks against experimental challenge with Clostridium perfringens. Vet. Microbiol. 2009, 133, 92-97. [CrossRef]

23. Kulkarni, R.R.; Parreira, V.R.; Sharif, S.; Prescott, J.F. Immunization of broiler chickens against Clostridium perfringens-induced necrotic enteritis. Clin. Vaccine Immunol. 2007, 14, 1070-1077. [CrossRef]

24. Kulkarni, R.R.; Parreira, V.R.; Sharif, S.; Prescott, J.F. Oral immunization of broiler chickens against necrotic enteritis with an attenuated Salmonella vaccine vector expressing Clostridium perfringens antigens. Vaccine 2008, 26, 4194-4203. [CrossRef]

25. Keyburn, A.L.; Portela, R.W.; Sproat, K.; Ford, M.E.; Bannam, T.L.; Yan, X.; Rood, J.I.; Moore, R.J. Vaccination with recombinant NetB toxin partially protects broiler chickens from necrotic enteritis. Vet. Res. 2013, 44, 54. [CrossRef]

26. Mot, D.; Timbermont, L.; Haesebrouck, F.; Ducatelle, R.; Van Immerseel, F. Progress and problems in vaccination against necrotic enteritis in broiler chickens. Avian Pathol. 2014, 43, 290-300. [CrossRef] [PubMed]

27. Plotkin, S.A. Introduction. In History of Vaccine Development; Plotkin, S., Ed.; Springer: New York, NY, USA, 2011 ; pp. 1-4. [CrossRef]

28. McReynolds, J.L.; Pillai, S.; Jesudhasan, P.R.; Hernandez, M.L.C. High Energy Electron Beam Irradiation for the Production of Immunomodulators in Poultry. U.S. Patent 8,173,139 B1, 8 May 2012.

29. Jesudhasan, P.R.; McReynolds, J.L.; Byrd, A.J.; He, H.; Genovese, K.J.; Droleskey, R.; Swaggerty, C.L.; Kogut, M.H.; Duke, S.; Nisbet, D.J.; et al. Electron-Beam-Inactivated Vaccine Against Salmonella Enteritidis Colonization in Molting Hens. Avian Dis. 2015, 59, 165-170. [CrossRef] [PubMed]

30. Bhatia, S.S.; Pillai, S.D. A Comparative Analysis of the Metabolomic Response of Electron Beam Inactivated E. coli O26:H11 and Salmonella Typhimurium ATCC 13311. Front. Microbiol. 2019, 10, 694. [CrossRef]

31. Fertey, J.; Bayer, L.; Grunwald, T.; Pohl, A.; Beckmann, J.; Gotzmann, G.; Casado, J.P.; Schonfelder, J.; Rogner, F.H.; Wetzel, C.; et al. Pathogens Inactivated by Low-Energy-Electron Irradiation Maintain Antigenic Properties and Induce Protective Immune Responses. Viruses 2016, 8. [CrossRef] [PubMed]

32. Barbara, A.J.; Trinh, H.T.; Glock, R.D.; Glenn Songer, J. Necrotic enteritis-producing strains of Clostridium perfringens displace non-necrotic enteritis strains from the gut of chicks. Vet. Microbiol. 2008, 126, 377-382. [CrossRef] [PubMed]

33. Cooper, K.K.; Songer, J.G. Virulence of Clostridium perfringens in an experimental model of poultry necrotic enteritis. Vet. Microbiol. 2010, 142, 323-328. [CrossRef] [PubMed]

34. Branton, S.L.; Reece, F.N.; Hagler, W.M., Jr. Influence of a wheat diet on mortality of broiler chickens associated with necrotic enteritis. Poult. Sci. 1987, 66, 1326-1330. [CrossRef] [PubMed]

35. Mollenhauer, H.H. Plastic Embedding Mixtures for Use in Electron Microscopy. Stain Technol. 1964, 39, 111-114.

36. McReynolds, J.L.; Byrd, J.A.; Anderson, R.C.; Moore, R.W.; Edrington, T.S.; Genovese, K.J.; Poole, T.L.; Kubena, L.F.; Nisbet, D.J. Evaluation of immunosuppressants and dietary mechanisms in an experimental disease model for necrotic enteritis. Poult. Sci. 2004, 83, 1948-1952. [CrossRef]

37. Olkowski, A.A.; Wojnarowicz, C.; Chirino-Trejo, M.; Drew, M.D. Responses of broiler chickens orally challenged with Clostridium perfringens isolated from field cases of necrotic enteritis. Res. Vet. Sci. 2006, 81, 99-108. [CrossRef] [PubMed]

38. Timbermont, L.; Lanckriet, A.; Gholamiandehkordi, A.R.; Pasmans, F.; Martel, A.; Haesebrouck, F.; Ducatelle, R.; Van Immerseel, F. Origin of Clostridium perfringens isolates determines the ability to induce necrotic enteritis in broilers. Comp. Immunol. Microbiol. Infect. Dis. 2009, 32, 503-512. [CrossRef] [PubMed]

39. Al-Sheikhly, F.; Al-Saieg, A. Role of Coccidia in the occurrence of necrotic enteritis of chickens. Avian Dis. 1980, 24, 324-333. [CrossRef] [PubMed]

40. Gholamiandehkordi, A.R.; Timbermont, L.; Lanckriet, A.; Van Den Broeck, W.; Pedersen, K.; Dewulf, J.; Pasmans, F.; Haesebrouck, F.; Ducatelle, R.; Van Immerseel, F. Quantification of gut lesions in a subclinical necrotic enteritis model. Avian Pathol. 2007, 36, 375-382. [CrossRef]

41. Collier, C.T.; Hofacre, C.L.; Payne, A.M.; Anderson, D.B.; Kaiser, P.; Mackie, R.I.; Gaskins, H.R. Coccidia-induced mucogenesis promotes the onset of necrotic enteritis by supporting Clostridium perfringens growth. Vet. Immunol. Immunopathol. 2008, 122, 104-115. [CrossRef] 
42. Park, S.S.; Lillehoj, H.S.; Allen, P.C.; Park, D.W.; FitzCoy, S.; Bautista, D.A.; Lillehoje, E.P. Immunopathology and cytokine responses in broiler chickens coinfected with Eimeria maxima and Clostridium perfringens with the use of an animal model of necrotic enteritis. Avian Dis. 2008, 52, 14-22. [CrossRef] [PubMed]

43. Pedersen, K.; Bjerrum, L.; Heuer, O.E.; Lo Fo Wong, D.M.; Nauerby, B. Reproducible infection model for Clostridium perfringens in broiler chickens. Avian Dis. 2008, 52, 34-39. [CrossRef] [PubMed]

44. Kogut, M.H.; McReynolds, J.L.; He, H.; Genovese, K.J.; Jesudhasan, P.R.; Davidson, M.A.; Cepeda, M.L.; Pillai, S.D. Electron-beam irradiation inactivation of salmonella: Effects on innate immunity and induction of protection against Salmonella enterica serovar Typhimurium challenge of chickens. Procedia Vaccinol. 2012, 6, 47-63. [CrossRef]

45. Burnside, K.; Lembo, A.; Harrell, M.I.; Klein, J.A.; Lopez-Guisa, J.; Siegesmund, A.M.; Torgerson, T.R.; Oukka, M.; Molina, D.M.; Rajagopal, L. Vaccination with a UV-irradiated genetically attenuated mutant of Staphylococcus aureus provides protection against subsequent systemic infection. J. Infect. Dis. 2012, 206, 1734-1744. [CrossRef]

46. Datta, S.K.; Okamoto, S.; Hayashi, T.; Shin, S.S.; Mihajlov, I.; Fermin, A.; Guiney, D.G.; Fierer, J.; Raz, E. Vaccination with irradiated Listeria induces protective T cell immunity. Immunity 2006, 25, 143-152. [CrossRef]

47. Jwa, M.Y.; Ko, E.B.; Kim, H.Y.; Kim, S.K.; Jeong, S.; Seo, H.S.; Yun, C.H.; Han, S.H. Gamma-irradiation-killed Streptococcus pneumoniae potently induces the expression of IL-6 and IL-8 in human bronchial epithelial cells. Microb Pathog. 2018, 124, 38-46. [CrossRef]

48. Jwa, M.Y.; Jeong, S.; Ko, E.B.; Kim, A.R.; Kim, H.Y.; Kim, S.K.; Seo, H.S.; Yun, C.H.; Han, S.H. Gamma-irradiation of Streptococcus pneumoniae for the use as an immunogenic whole cell vaccine. J. Microbiol. 2018, 56, 579-585. [CrossRef]

49. Magnani, D.M.; Harms, J.S.; Durward, M.A.; Splitter, G.A. Nondividing but metabolically active gamma-irradiated Brucella melitensis is protective against virulent B. melitensis challenge in mice. Infect. Immun. 2009, 77, 5181-5189. [CrossRef]

50. Sanakkayala, N.; Sokolovska, A.; Gulani, J.; Hogenesch, H.; Sriranganathan, N.; Boyle, S.M.; Schurig, G.G.; Vemulapalli, R. Induction of antigen-specific Th1-type immune responses by gamma-irradiated recombinant Brucella abortus RB51. Clin. Diagn. Lab. Immunol. 2005, 12, 1429-1436. [CrossRef] [PubMed]

51. Van Diemen, P.M.; Yamaguchi, Y.; Paterson, G.K.; Rollier, C.S.; Hill, A.V.; Wyllie, D.H. Irradiated wild-type and Spa mutant Staphylococcus aureus induce anti-S. aureus immune responses in mice which do not protect against subsequent intravenous challenge. Pathog. Dis. 2013, 68, 20-26. [CrossRef] [PubMed]

52. Alsharifi, M.; Furuya, Y.; Bowden, T.R.; Lobigs, M.; Koskinen, A.; Regner, M.; Trinidad, L.; Boyle, D.B.; Mullbacher, A. Intranasal flu vaccine protective against seasonal and H5N1 avian influenza infections. PLoS ONE 2009, 4, e5336. [CrossRef] [PubMed]

53. Furuya, Y.; Chan, J.; Regner, M.; Lobigs, M.; Koskinen, A.; Kok, T.; Manavis, J.; Li, P.; Mullbacher, A.; Alsharifi, M. Cytotoxic T cells are the predominant players providing cross-protective immunity induced by \{gamma\}-irradiated influenza A viruses. J. Virol. 2010, 84, 4212-4221. [CrossRef] [PubMed]

54. Lacey, J.A.; Keyburn, A.L.; Ford, M.E.; Portela, R.W.; Johanesen, P.A.; Lyras, D.; Moore, R.J. Conjugation-Mediated Horizontal Gene Transfer of Clostridium perfringens Plasmids in the Chicken Gastrointestinal Tract Results in the Formation of New Virulent Strains. Appl. Environ. Microbiol. 2017, 83. [CrossRef] [PubMed]

55. Centers for Disease Control and Prevention (CDC). Surveillance for Foodborne Disease Outbreaks United States, 2017: Annual Report; U.S. Department of Health and Human Services: Atlanta, GA, USA, 2019; pp. 1-10.

56. Mora, Z.V.; Macias-Rodriguez, M.E.; Arratia-Quijada, J.; Gonzalez-Torres, Y.S.; Nuno, K.; Villarruel-Lopez, A. Clostridium perfringens as Foodborne Pathogen in Broiler Production: Pathophysiology and Potential Strategies for Controlling Necrotic Enteritis. Animals 2020, 10. [CrossRef]

57. Babb, R.; Chen, A.; Ogunniyi, A.D.; Hirst, T.R.; Kara, E.E.; McColl, S.R.; Alsharifi, M.; Paton, J.C. Enhanced protective responses to a serotype-independent pneumococcal vaccine when combined with an inactivated influenza vaccine. Clin. Sci. 2017, 131, 169-180. [CrossRef]

58. Bayer, L.; Fertey, J.; Ulbert, S.; Grunwald, T. Immunization with an adjuvanted low-energy electron irradiation inactivated respiratory syncytial virus vaccine shows immunoprotective activity in mice. Vaccine 2018, 36, 1561-1569. [CrossRef]

59. Feng, G.; Liu, L.; Cui, W.; Wang, F. Electron beam irradiation on novel coronavirus (COVID-19): A Monte-Carlo simulation. Chin. Phys. B. 2020, 29, 048703. [CrossRef]

60. Sabbaghi, A.; Miri, S.M.; Keshavarz, M.; Zargar, M.; Ghaemi, A. Inactivation methods for whole influenza vaccine production. Rev. Med. Virol. 2019, 29, e2074. [CrossRef] [PubMed]

61. Shahrudin, S.; Chen, C.; David, S.C.; Singleton, E.V.; Davies, J.; Kirkwood, C.D.; Hirst, T.R.; Beard, M.; Alsharifi, M. Gammairradiated rotavirus: A possible whole virus inactivated vaccine. PLoS ONE 2018, 13, e0198182. [CrossRef] [PubMed]

62. Walker, P.D. Bacterial vaccines: Old and new, veterinary and medical. Vaccine 1992, 10, 977-990. [CrossRef]

63. Pillai, S.D.; Pillai, E.T. Electron beam irradiation technology applications in the food industry. In Encyclopedia of Nuclear Energy ist Ed; Elsevier Book: Amsterdam, The Netherlands, 2021; Chapter 8; ISBN 9780128197257.

64. Praveen, C.; Bhatia, S.S.; Alaniz, R.C.; Droleskey, R.E.; Cohen, N.D.; Jesudhasan, P.R.; Pillai, S.D. Assessment of microbiological correlates and immunostimulatory potential of electron beam inactivated metabolically active yet non culturable (MAyNC) Salmonella Typhimurium. PLoS ONE. In press. 